\title{
Synthesis of Novel Diclofenac Hydrazones: Molecular Docking, Anti-Inflammatory, Analgesic, and Ulcerogenic Activity
}

\author{
Nawaf A. Alsaif, ${ }^{1}$ Mashooq A. Bhat ${ }^{(D},{ }^{1}$ Mohamed A. Al-Omar, ${ }^{1}$ Hanaa M. Al-Tuwajiri, ${ }^{1}$ \\ Ahmed M. Naglah, ${ }^{2,3}$ and Abdullah Al-Dhfyan ${ }^{4,5}$ \\ ${ }^{1}$ Department of Pharmaceutical Chemistry, College of Pharmacy, King Saud University, Riyadh 11451, Saudi Arabia \\ ${ }^{2}$ Department of Pharmaceutical Chemistry, Drug Exploration and Development Chair (DEDC), College of Pharmacy, \\ King Saud University, Riyadh 11451, Saudi Arabia \\ ${ }^{3}$ Peptide Chemistry Department, Chemical Industries Research Division, National Research Centre, Dokki, Cairo 12622, Egypt \\ ${ }^{4}$ Stem Cell \& Tissue Re-Engineering Program, Research Center, King Faisal Specialized Hospital and Research Center, MBC-03, \\ PO Box 3354, Riyadh 11211, Saudi Arabia \\ ${ }^{5}$ Department of Pharmacology and Toxicology, College of Pharmacy, King Saud University, Riyadh 11451, Saudi Arabia
}

Correspondence should be addressed to Mashooq A. Bhat; mabhat@ksu.edu.sa

Received 14 July 2020; Revised 9 November 2020; Accepted 24 November 2020; Published 10 December 2020

Academic Editor: Maria Grazia Perrone

Copyright (c) 2020 Nawaf A. Alsaif et al. This is an open access article distributed under the Creative Commons Attribution License, which permits unrestricted use, distribution, and reproduction in any medium, provided the original work is properly cited.

\begin{abstract}
This study was aimed to design novel diclofenac hydrazones having anti-inflammatory and analgesic activity with gastric sparing effect. A new series of 2-[2-(2,6-dichloroanilino)phenyl]-N'-[(substituted phenyl) methylidene] acetohydrazide derivatives (1-14) were synthesized and evaluated for their anti-inflammatory, analgesic, and ulcerogenic activity. The compounds were identified and confirmed by elemental analysis and spectral data. During anti-inflammatory activity by carrageenan-induced paw edema method, compounds $(2,3,7,8,11$, and 13) were found to be most promising. Compounds 3, 8, and 13 have been found to have significant analgesic activity compared to the reference drug diclofenac in analgesic activity by both the hot plate method and acetic acid-induced writhing method. The compounds which presented highly significant anti-inflammatory and analgesic activity were further tested for their ulcerogenic activity. Compounds 3 and 8 showed maximum ulcerogenic reduction activities. Compound 8 was found to have LD50 of $168 \mathrm{mg} / \mathrm{kg}$. Compound 8 with 3,5-dimethoxy-4-hydroxyphenyl substitution was found to be the most promising anti-inflammatory and analgesic agent with gastric sparing activity. Molecular docking of compounds was performed for COX-1/COX-2 binding site. Lead compound 8 showed better binding affinities of $-9.4 \mathrm{~kJ} / \mathrm{mol}$ with both COX-1 and COX-2 as compared to the standard drug, diclofenac with binding affinities of $-6.6 \mathrm{~kJ} / \mathrm{mol}$ and $-8.1 \mathrm{~kJ} / \mathrm{mol}$ for COX -1 and COX-2, respectively.
\end{abstract}

\section{Introduction}

Diclofenac is a phenyl acetic acid derivative with anti-inflammatory, analgesic, and antipyretic activity. It is a widely used NSAID for the treatment of chronic inflammatory diseases. Diclofenac is associated with serious dose-dependent gastrointestinal, cardiovascular, and renal effects. Prolonged use of diclofenac has caused gastric ulcer and bleeding. The pharmacological activity of diclofenac is the cyclooxygenase enzyme inhibition, resulting in the inhibition of prostaglandin biosynthesis from arachidonic acid [1]. Diclofenac is a nonselective COX inhibitor with complete absorption and extensive metabolism. Selective COX-2 inhibitors like celecoxib, rofecoxib, and etoricoxib are reported to have less gastrointestinal side effects [2].

Synthetic approaches based on chemical modification have been used to improve the safety profile of drugs $[3,4]$. Many modification methods were used, for example, hybridization and prodrugs [5-7]. Derivatization of carboxylic acid moiety of NSAIDs has resulted in an increase in anti-inflammatory with 
reduced ulcerogenic effect [8-13]. Amide modification causes greater selectivity for COX-2, resulting in gastroprotection $[14,15]$. The active site in COX-2 is bigger than the active site of COX-1 enzyme, so changing the size of the drug molecule may improve the binding against COX-2 [16]. Therefore, the development of NSAID with an improved safety profile is still in demand. Literature survey revealed that modification of carboxylic acid moiety of diclofenac has produced significant pharmacological results $[11,15,17-19]$.

In continuation of our research in this field, herein we have synthesized novel diclofenac hydrazone derivatives and evaluated their potential anti-inflammatory, analgesic, and ulcerogenic activity $[20,21]$.

\section{Experiment}

2.1. Chemistry. All the solvents were purchased from Merck. Compound purity was checked by thin-layer chromatography (TLC) and was carried out on silica gel $60 \mathrm{~F}_{254}$ coated plates (Merck). FT-IR was determined by Perkin Elmer FTIR spectrophotometer. Melting points were checked by Gallenkamp melting point apparatus. ${ }^{1} \mathrm{H}$ and ${ }^{13} \mathrm{C}$ NMR of the compounds were determined by Bruker NMR $500 \mathrm{MHz}$ and $125 \mathrm{MHz}$ spectrophotometer, respectively. Molecular weights of compounds were determined by Agilent triple quadrupole 6410 TQ GC/MS. Elemental analysis was carried out by Elementar (Analysensysteme $\mathrm{GmbH}$, Germany). The molecular docking simulations were performed using CBDock online server. This server employed Autodock vina for protein-ligand docking. Usually, the binding affinity of the docked ligand with the protein is estimated with vina score, which is also known as docking energies $(\mathrm{kJ} / \mathrm{mol})$. The bestdocked compound typically demonstrates low vina score or docking energies.

2.2. Synthesis of Methyl [2-(2,6-Dichloroanilino)phenyl]acetate (II). The diclofenac ester was synthesized as per the reported procedure [22].

2.3. Synthesis of 2-[2-(2,6-Dichloroanilino)phenyl]acetohydrazide (III). The methyl ester of diclofenac $(0.01 \mathrm{~mol})$ and hydrazine hydrate $(99 \%)(0.2 \mathrm{~mol})$ were allowed to reflux in methanol $(50 \mathrm{~mL})$ for 30 hours. The reaction mixture was added to the ice-cold water. The white solid product was obtained, which was filtered by vacuum filtration, dried, and recrystallized from ethanol. Yield: $80 \%$; m.p.: $180-182{ }^{\circ} \mathrm{C} ;{ }^{1} \mathrm{H}$ NMR (500 MHz, DMSO-d $\left.{ }_{6}\right): \delta=1.97\left(2 \mathrm{H}, \mathrm{s}, \mathrm{NH}_{2}\right), 3.73$ (1H, s, CH), 4.00 (1H, s, CH), 6.26-7.88 (7H, m, Ar-H), 8.31 (1H, s, NHPh, $\mathrm{D}_{2} \mathrm{O}$ exchg.), $10.41\left(1 \mathrm{H}, \mathrm{s}, \mathrm{CONH}, \mathrm{D}_{2} \mathrm{O}\right.$ exchg.) $[23,24]$.

2.4. General Procedure for the Synthesis of 2-[2-(2,6Dichloroanilino)phenyl]-N'-[(substituted phenyl)methylidene]acetohydrazide (1-14). A solution of diclofenac hydrazide $(1.0 \mathrm{mmol})$ containing appropriate substituted benzaldehydes $(1.1 \mathrm{mmol})$ in ethanol $(50 \mathrm{~mL})$ and glacial acetic acid (3 drops) was allowed to reflux for 3 hours on a heating mantle. After the completion of the reaction, the reaction mixture was poured into the ice-cold water in a beaker. The white product was collected by vacuum filtration. The solid product was purified by recrystallization from ethanol.

2.4.1. 2-[2-(2,6-Dichloroanilino)phenyl]-N'-[(3-methoxyphenyl)methylidene]acetohydrazide (1). Yield: 70\%; m.p.: $248-250^{\circ} \mathrm{C} ;{ }^{1} \mathrm{H}$ NMR $\left(500 \mathrm{MHz}, \mathrm{DMSO}-\mathrm{d}_{6}\right): \delta=3.67(1 \mathrm{H}, \mathrm{s}$, $\left.\mathrm{CH}_{2}\right), 3.89\left(3 \mathrm{H}, \mathrm{s}, \mathrm{OCH}_{3}\right), 4.14\left(1 \mathrm{H}, \mathrm{s}, \mathrm{CH}_{2}\right), 6.39-7.75(11 \mathrm{H}$, $\mathrm{m}, \operatorname{Ar}-\mathrm{H}), 8.04(1 \mathrm{H}, \mathrm{s},=\mathrm{CH}), 8.91\left(1 \mathrm{H}, \mathrm{s}, \mathrm{NHPh}, \mathrm{D}_{2} \mathrm{O}\right.$ exchg.), 11.60 (1H, s, CONH, $\mathrm{D}_{2} \mathrm{O}$ exchg.); ${ }^{13} \mathrm{C} \mathrm{NMR}$ $\left(125.76 \mathrm{MHz}, \mathrm{DMSO}-\mathrm{d}_{6}\right): \delta=55.5,55.68,56.5,108.9,123.3$, 125.0, 125.4, 128.3, 129.6, 129.8, 130.3, 132.4, 134.9, 143.2, 173.7; MS: $m / z=428.31[\mathrm{M}]^{+}$; analysis: for $\mathrm{C}_{22} \mathrm{H}_{19} \mathrm{Cl}_{2} \mathrm{~N}_{3} \mathrm{O}_{2}$; calcd. C 61.69, H 4.47, N 9.81\%; found C 61.45, H 4.46, N $9.84 \%$.

2.4.2. 2-[2-(2,6-Dichloroanilino)phenyl]-N'-[(2,3-dimethoxyphenyl)methylidene]acetohydrazide (2). Yield: 75\%; m.p.: $240-242^{\circ} \mathrm{C}$; ${ }^{1} \mathrm{H}$ NMR $\left(500 \mathrm{MHz}, \mathrm{DMSO}-\mathrm{d}_{6}\right): \delta=3.67(1 \mathrm{H}, \mathrm{s}$, $\left.\mathrm{CH}_{2}\right), 3.89\left(6 \mathrm{H}, \mathrm{s}, 2 \times \mathrm{OCH}_{3}\right), 4.14\left(1 \mathrm{H}, \mathrm{s}, \mathrm{CH}_{2}\right), 6.39-7.75$ $(11 \mathrm{H}, \mathrm{m}, \mathrm{Ar}-\mathrm{H}), 8.04(1 \mathrm{H}, \mathrm{s},=\mathrm{CH}), 8.91\left(1 \mathrm{H}, \mathrm{s}, \mathrm{NHPh}, \mathrm{D}_{2} \mathrm{O}\right.$ exchg.), 11.60 (1H, s, CONH, $\mathrm{D}_{2} \mathrm{O}$ exchg.); ${ }^{13} \mathrm{C} \mathrm{NMR}$ $\left(125.76 \mathrm{MHz}, \mathrm{DMSO}-\mathrm{d}_{6}\right): \delta=56.2,56.3,61.1,61.6,109.6$, $114.6,115.6,121.4,123.2,124.7,126.6,127.8,129.9,132.5$, $135.1,137.4,140.2,143.4,143.6,147.9,153.1,166.3,168.2$, 173.3; MS: $m / z=458.33[\mathrm{M}]^{+}$; analysis: for $\mathrm{C}_{23} \mathrm{H}_{21} \mathrm{Cl}_{2} \mathrm{~N}_{3} \mathrm{O}_{3}$ calcd. C 60.27, H 4.62, N 9.17\%; found C 60.03, H 4.63, N $9.20 \%$.

2.4.3. 2-[2-(2,6-Dichloroanilino)phenyl]-N'-[(2,4-dimethoxyphenyl)methylidene]acetohydrazide (3). Yield: 73\%; m.p.: $200-202^{\circ} \mathrm{C}$; ${ }^{1} \mathrm{H}$ NMR $\left(500 \mathrm{MHz}, \mathrm{DMSO}-\mathrm{d}_{6}\right): \delta=3.67(1 \mathrm{H}, \mathrm{s}$, $\left.\mathrm{CH}_{2}\right), 3.84\left(6 \mathrm{H}, \mathrm{s}, 2 \times \mathrm{OCH}_{3}\right), 4.11\left(1 \mathrm{H}, \mathrm{s}, \mathrm{CH}_{2}\right), 6.39-7.81$ $(11 \mathrm{H}, \mathrm{m}, \mathrm{Ar}-\mathrm{H}), 8.18(1 \mathrm{H}, \mathrm{s},=\mathrm{CH}), 8.31\left(1 \mathrm{H}, \mathrm{s}, \mathrm{NHPh}, \mathrm{D}_{2} \mathrm{O}\right.$ exchg.), 11.41 (1H, s, CONH, $\mathrm{D}_{2} \mathrm{O}$ exchg.); ${ }^{13} \mathrm{C} \mathrm{NMR}$ $\left(125.76 \mathrm{MHz}, \mathrm{DMSO}-\mathrm{d}_{6}\right): \delta=55.9,98.6,98.7,106.8,106.9$, $108.9,123.3,125.4,128.3,129.6,129.8,132.4,134.9,140.3$, 143.2, 143.5, 159.5, 159.6, 162.8, 163.0, 167.8, 173.0, 173.7; MS: $m / z=458.33[\mathrm{M}]^{+}$; analysis: for $\mathrm{C}_{23} \mathrm{H}_{21} \mathrm{Cl}_{2} \mathrm{~N}_{3} \mathrm{O}_{3}$ calcd. C 60.27, H 4.62, N 9.17\%; found C 60.04, H 4.61, N 9.14\%.

2.4.4. 2-[2-(2,6-Dichloroanilino)phenyl]-N'-[(2-hydroxy,3methoxyphenyl)methylidene] acetohydrazide (4). Yield: 68\%; m.p.: $248-250{ }^{\circ} \mathrm{C} ;{ }^{1} \mathrm{H}$ NMR $\left(500 \mathrm{MHz}, \mathrm{DMSO}-\mathrm{d}_{6}\right): \delta=3.67$ $\left(1 \mathrm{H}, \mathrm{s}, \mathrm{CH}_{2}\right), 3.81\left(3 \mathrm{H}, \mathrm{s}, \mathrm{OCH}_{3}\right), 4.11\left(1 \mathrm{H}, \mathrm{s}, \mathrm{CH}_{2}\right), 6.29-7.99$ $(10 \mathrm{H}, \mathrm{m}, \mathrm{Ar}-\mathrm{H}), 8.41(1 \mathrm{H}, \mathrm{s},=\mathrm{CH}), 8.48\left(1 \mathrm{H}, \mathrm{s}, \mathrm{NHPh}, \mathrm{D}_{2} \mathrm{O}\right.$ exchg.), 10.6 (1H, s, OH, $\mathrm{D}_{2} \mathrm{O}$ exchg.), $11.60(1 \mathrm{H}, \mathrm{s}, \mathrm{CONH}$, $\mathrm{D}_{2} \mathrm{O}$ exchg.); ${ }^{13} \mathrm{C}$ NMR $\left(125.76 \mathrm{MHz}, \mathrm{DMSO}-\mathrm{d}_{6}\right): \delta=56.2$, $56.3,114.2,116.5,119.5,120.8,121.3,125.8,128.0,129.6$, $130.1,137.5,141.8,143.4,146.4,147.4,147.7,148.3,168.0$, 173.1; MS: $m / z=444.310[\mathrm{M}]^{+}$; analysis: for $\mathrm{C}_{22} \mathrm{H}_{19} \mathrm{Cl}_{2} \mathrm{~N}_{3} \mathrm{O}_{2}$ calcd. C 59.47, H 4.31, N 9.46\%; found C 59.60, H 4.30, N $9.43 \%$. 
2.4.5. 2-[2-(2,6-Dichloroanilino)phenyl]-N'-[(3-ethoxy-4hydroxyphenyl)methylidene]acetohydrazide (5). Yield: 65\%; m.p.: $243-245^{\circ} \mathrm{C} ;{ }^{1} \mathrm{H}$ NMR $\left(500 \mathrm{MHz}, \mathrm{DMSO}-\mathrm{d}_{6}\right): \delta=1.35$ $\left(3 \mathrm{H}, \mathrm{t}, \mathrm{CH}_{3}\right), 3.69\left(1 \mathrm{H}, \mathrm{s}, \mathrm{CH}_{2}\right), 3.89\left(2 \mathrm{H}, \mathrm{q}, \mathrm{OCH}_{2}\right), 4.11(1 \mathrm{H}$, s, $\left.\mathrm{CH}_{2}\right), 6.39-7.76(10 \mathrm{H}, \mathrm{m}, \mathrm{Ar}-\mathrm{H}), 7.95(1 \mathrm{H}, \mathrm{s},=\mathrm{CH}), 8.11$ (1H, s, NHPh, $\mathrm{D}_{2} \mathrm{O}$ exchg.), 9.51 ( $1 \mathrm{H}, \mathrm{s}, \mathrm{OH}, \mathrm{D}_{2} \mathrm{O}$ exchg.), 11.48 (1H, s, CONH, $\mathrm{D}_{2} \mathrm{O}$ exchg.); ${ }^{13} \mathrm{C} \mathrm{NMR}(125.76 \mathrm{MHz}$, DMSO- $\left.\mathrm{d}_{6}\right): \delta=15.1,35.5,64.1,108.9,123.3,125.4,128.2$, $129.8,132.4,134.9,143.2,147.6,173.7$; MS: $m / z=458.33$ $[\mathrm{M}]^{+}$; analysis: for $\mathrm{C}_{22} \mathrm{H}_{19} \mathrm{Cl}_{2} \mathrm{~N}_{3} \mathrm{O}_{3}$ calcd. C 59.47, $\mathrm{H} 4.31, \mathrm{~N}$ 9.46\%; found C 59.24, H 4.32, N 9.49\% [25].

2.4.6. 2-[2-(2,6-Dichloroanilino)phenyl]-N'-[(4-chlorophenyl)methylidene]acetohydrazide (6). Yield: 80\%; m.p.: $198-200^{\circ} \mathrm{C} ;{ }^{1} \mathrm{H}$ NMR $\left(500 \mathrm{MHz}, \mathrm{DMSO}-\mathrm{d}_{6}\right): \delta=3.73(1 \mathrm{H}, \mathrm{s}$, $\left.\mathrm{CH}_{2}\right), 4.15\left(1 \mathrm{H}, \mathrm{s}, \mathrm{CH}_{2}\right), 6.30-7.76(11 \mathrm{H}, \mathrm{m}, \mathrm{Ar}-\mathrm{H}), 8.06(1 \mathrm{H}$, $\mathrm{s},=\mathrm{CH}), 8.24\left(1 \mathrm{H}, \mathrm{s}, \mathrm{NHPh}, \mathrm{D}_{2} \mathrm{O}\right.$ exchg.), $11.71(1 \mathrm{H}, \mathrm{s}$, $\mathrm{CONH}, \mathrm{D}_{2} \mathrm{O}$ exchg.); ${ }^{13} \mathrm{C}$ NMR $\left(125.76 \mathrm{MHz}, \mathrm{DMSO}-\mathrm{d}_{6}\right)$ : $\delta=108.9,123.3,125.4,128.2,129.0,129.3,129.4,129.6$, $129.8,130.4,132.3,134.9,143.1,143.2,146.6,168.4,173.5$, 173.7; MS: $m / z=432.73[\mathrm{M}]^{+}$; analysis: for $\mathrm{C}_{21} \mathrm{H}_{16} \mathrm{Cl}_{3} \mathrm{~N}_{3} \mathrm{O}$ calcd. C 58.29, H 3.73, N 9.71\%; found C 58.15, H 3.74, N 9.74\%.

2.4.7. 2-[2-(2,6-Dichloroanilino)phenyl]-N'-[(3-ethoxy-2hydroxyphenyl)methylidene] acetohydrazide (7). Yield: 60\%; m.p.: $246-248^{\circ} \mathrm{C} ;{ }^{1} \mathrm{H}$ NMR $\left(500 \mathrm{MHz}, \mathrm{DMSO}-\mathrm{d}_{6}\right): \delta=1.36$ $\left(3 \mathrm{H}, \mathrm{t}, \mathrm{CH}_{3}\right), 3.74\left(1 \mathrm{H}, \mathrm{s}, \mathrm{CH}_{2}\right), 3.84\left(3 \mathrm{H}, \mathrm{s}, \mathrm{OCH}_{2}\right), 4.07(1 \mathrm{H}$, q, $\left.\mathrm{CH}_{2}\right), 6.38-7.76(10 \mathrm{H}, \mathrm{m}, \mathrm{Ar}-\mathrm{H}), 8.01(1 \mathrm{H}, \mathrm{s},=\mathrm{CH}), 8.48$ (1H, s, NHPh, $\mathrm{D}_{2} \mathrm{O}$ exchg.), 10.60 ( $1 \mathrm{H}, \mathrm{s}, \mathrm{OH}, \mathrm{D}_{2} \mathrm{O}$ exchg.), 11.60 (1H, s, CONH, D $2 \mathrm{O}$ exchg.); ${ }^{13} \mathrm{C}$ NMR $(125.76 \mathrm{MHz}$, DMSO $\left.-\mathrm{d}_{6}\right): \delta=15.1,64.5,108.9,123.3,125.0,125.4,128.2$, 129.6, 130.1, 132.3, 134.9, 143.2, 147.5, 167.9, 173.7; MS: $m /$ $z=458.33[\mathrm{M}]^{+}$; analysis: for $\mathrm{C}_{23} \mathrm{H}_{21} \mathrm{Cl}_{2} \mathrm{~N}_{3} \mathrm{O}_{3}$ calcd. C 60.27, $\mathrm{H}$ 4.62, N 9.17\%; found C 60.04, H 4.63, N 9.20\%.

2.4.8. 2-[2-(2,6-Dichloroanilino)phenyl]-N'-[(3,5-dimethoxy4-hydroxy-phenyl)methylidene]acetohydrazide (8). Yield: $60 \%$; m.p.: $235-237^{\circ} \mathrm{C}$; ${ }^{1} \mathrm{H}$ NMR (500 MHz, DMSO-d ${ }_{6}$ ): $\delta=3.74\left(1 \mathrm{H}, \mathrm{s}, \mathrm{CH}_{2}\right), 3.80\left(6 \mathrm{H}, \mathrm{s}, 2 \times \mathrm{OCH}_{3}\right), 4.11(1 \mathrm{H}, \mathrm{s}$, $\left.\mathrm{CH}_{2}\right), 6.27-7.72(9 \mathrm{H}, \mathrm{m}, \mathrm{Ar}-\mathrm{H}), 7.95(1 \mathrm{H}, \mathrm{s},=\mathrm{CH}), 8.12(1 \mathrm{H}$, s, NHPh, $\mathrm{D}_{2} \mathrm{O}$ exchg.), $8.94\left(1 \mathrm{H}, \mathrm{s}, \mathrm{OH}, \mathrm{D}_{2} \mathrm{O}\right.$ exchg. $), 11.50$ $\left(1 \mathrm{H}, \mathrm{s}, \mathrm{CONH}, \mathrm{D}_{2} \mathrm{O}\right.$ exchg.); ${ }^{13} \mathrm{C} \mathrm{NMR}(125.76 \mathrm{MHz}$, DMSO- $\left.\mathrm{d}_{6}\right): \delta=56.3,56.5,104.8,105.2,115.8,120.9,121.3$, $124.4,125.4,126.1,127.8,129.6,130.0,137.3,138.2,138.5$, $143.5,145.0,148.5,148.6,167.9,173.0 ; \mathrm{MS}: \mathrm{m} / z=474.33$ $[\mathrm{M}]^{+}$; analysis: for $\mathrm{C}_{23} \mathrm{H}_{21} \mathrm{Cl}_{2} \mathrm{~N}_{3} \mathrm{O}_{4}$ calcd.; $\mathrm{C} 58.24, \mathrm{H} 4.46, \mathrm{~N}$ $8.86 \%$; found C 58.02, H 4.45, N 8.89\%.

2.4.9. 2-[2-(2,6-Dichloroanilino)phenyl]-N'-[(2,4,6-trimethoxyphenyl)methylidene]acetohydrazide (9). Yield: $75 \%$; m.p.: $248-250^{\circ} \mathrm{C} ;{ }^{1} \mathrm{H}$ NMR $\left(500 \mathrm{MHz}, \mathrm{DMSO}-\mathrm{d}_{6}\right): \delta=3.73$ $\left(1 \mathrm{H}, \mathrm{s}, \mathrm{CH}_{2}\right), 3.79\left(9 \mathrm{H}, \mathrm{s}, 3 \times \mathrm{OCH}_{3}\right), 4.03\left(1 \mathrm{H}, \mathrm{s}, \mathrm{CH}_{2}\right)$, 6.23-7.54 (9H, m, Ar-H), $7.92(1 \mathrm{H}, \mathrm{s},=\mathrm{CH}), 8.32(1 \mathrm{H}, \mathrm{s}$, NHPh, $\mathrm{D}_{2} \mathrm{O}$ exchg.), 11.10 (1H, s, CONH, $\mathrm{D}_{2} \mathrm{O}$ exchg.); ${ }^{13} \mathrm{C}$ NMR $\left(125.76 \mathrm{MHz}, \quad \mathrm{DMSO}-\mathrm{d}_{6}\right): \delta=55.9, \quad 56.3,56.4$, $104.0,115.0,120.4,123.7,126.4,127.7,129.6,131.5,131.8$,
$137.2,140.2,143.3,160.3,160.4,162.7,167.5,172.7 ;$ MS: m/ $\mathrm{Z}=488.36[\mathrm{M}]^{+}$; analysis: for $\mathrm{C}_{24} \mathrm{H}_{23} \mathrm{Cl}_{2} \mathrm{~N}_{3} \mathrm{O}_{4}$ calcd. C 59.03, $\mathrm{H}$ 4.75, N 8.60\%; found C 59.21, H 4.74, N 8.62\%.

2.4.10. 2-[2-(2,6-Dichloroanilino)phenyl]-N'-[(2,4,5-trimethoxyphenyl)methylidene]acetohydrazide (10). Yield: 73\%; m.p.: $245-247^{\circ} \mathrm{C} ;{ }^{1} \mathrm{H}$ NMR (500 MHz, DMSO-d 6 ): $\delta=3.67$ $\left(1 \mathrm{H}, \mathrm{s}, \mathrm{CH}_{2}\right), 3.86\left(9 \mathrm{H}, \mathrm{s}, 3 \times \mathrm{OCH}_{3}\right), 4.03\left(1 \mathrm{H}, \mathrm{s}, \mathrm{CH}_{2}\right)$, 6.39-7.77 (9H, m, Ar-H), $8.14(1 \mathrm{H}, \mathrm{s},=\mathrm{CH}), 8.33(1 \mathrm{H}, \mathrm{s}$, $\mathrm{NHPh}, \mathrm{D}_{2} \mathrm{O}$ exchg.); 11.47 (1H, s, CONH, $\mathrm{D}_{2} \mathrm{O}$ exchg.); ${ }^{13} \mathrm{C}$ NMR $\left(125.76 \mathrm{MHz}, \mathrm{DMSO}-\mathrm{d}_{6}\right): \delta=56.1,56.2,56.4,56.9$, $57.0,98.3,108.9,123.3,125.0,125.4,128.2,129.6,129.9$, $130.3,130.6,132.4,140.2,143.3,143.5,152.3,153.6,167.8$, 172.9, 173.3; MS: $m / z=488.36[\mathrm{M}]^{+}$; analysis: for $\mathrm{C}_{24} \mathrm{H}_{23} \mathrm{Cl}_{2} \mathrm{~N}_{3} \mathrm{O}_{4}$ calcd. C 59.03, $\mathrm{H} 4.75, \mathrm{~N} 8.60 \%$; found $\mathrm{C}$ 59.23, H 4.74, N 8.63\%.

2.4.11. 2-[2-(2,6-Dichloroanilino)phenyl]-N'-[(3-methoxy-4ethoxyphenyl)methylidene]acetohydrazide (11). Yield: 70\%; m.p.: $210-212^{\circ} \mathrm{C} ;{ }^{1} \mathrm{H}$ NMR (500 MHz, DMSO- $\left.\mathrm{d}_{6}\right): \delta=1.35$ $\left(3 \mathrm{H}, \mathrm{t}, \mathrm{CH}_{3}\right), 3.70\left(1 \mathrm{H}, \mathrm{s}, \mathrm{CH}_{2}\right), 3.81\left(3 \mathrm{H}, \mathrm{s}, \mathrm{OCH}_{3}\right), 4.0(2 \mathrm{H}$, s, $\left.\mathrm{OCH}_{2}\right), 4.12\left(1 \mathrm{H}, \mathrm{s}, \mathrm{CH}_{2}\right), 6.28-7.99(10 \mathrm{H}, \mathrm{m}, \mathrm{Ar}-\mathrm{H}), 8.12$ $(1 \mathrm{H}, \mathrm{s},=\mathrm{CH}), 8.18\left(1 \mathrm{H}, \mathrm{s}, \mathrm{NHPh}, \mathrm{D}_{2} \mathrm{O}\right.$ exchg. $), 11.56(1 \mathrm{H}, \mathrm{s}$, CONH, $\mathrm{D}_{2} \mathrm{O}$ exchg.); ${ }^{13} \mathrm{C}$ NMR $\left(125.76 \mathrm{MHz}, \mathrm{DMSO}-\mathrm{d}_{6}\right)$ : $\delta=15.1,55.7,55.9,64.2,108.9,112.7,115.9,121.0,122.4$, $125.7,126.1,127.8,129.6,130.0,130.6,137.4,143.4,144.6$, $148.3,149.5,150.3,150.5,168.0,173.1$; MS: $m / z=472.36$ $[\mathrm{M}]^{+}$; analysis: for $\mathrm{C}_{24} \mathrm{H}_{23} \mathrm{Cl}_{2} \mathrm{~N}_{3} \mathrm{O}_{3}$ calcd. C 61.02, $\mathrm{H} 4.91, \mathrm{~N}$ $8.90 \%$; found C $61.26, \mathrm{H} 4.90, \mathrm{~N} 8.92 \%$.

2.4.12. 2-[2-(2,6-Dichloroanilino)phenyl]-N'-[(2,3-dihydroxyphenyl)methylidene] acetohydrazide (12). Yield: 70\%; m.p.: $208-210^{\circ} \mathrm{C} ;{ }^{1} \mathrm{H}$ NMR $\left(500 \mathrm{MHz}, \mathrm{DMSO}-\mathrm{d}_{6}\right): \delta=3.74(1 \mathrm{H}, \mathrm{s}$, $\left.\mathrm{CH}_{2}\right), 4.11\left(1 \mathrm{H}, \mathrm{s}, \mathrm{CH}_{2}\right), 6.32-7.75(10 \mathrm{H}, \mathrm{m}, \mathrm{Ar}-\mathrm{H}), 7.99(1 \mathrm{H}$, s, =CH), $8.42\left(1 \mathrm{H}, \mathrm{s}, \mathrm{NHPh}, \mathrm{D}_{2} \mathrm{O}\right.$ exchg.), $9.30(1 \mathrm{H}, \mathrm{s}, \mathrm{OH}$, $\mathrm{D}_{2} \mathrm{O}$ exchg.), 10.82 (1H, s, OH, $\mathrm{D}_{2} \mathrm{O}$ exchg.), $11.59(1 \mathrm{H}, \mathrm{s}$, CONH, $\mathrm{D}_{2} \mathrm{O}$ exchg.); ${ }^{13} \mathrm{C}$ NMR (125.76 MHz, DMSO-d 6 ): $\delta=116.5,117.9,119.1,120.2,121.0,124.9,125.8,128.0$, $129.6,130.1,130.5,131.0,137.5,143.4,146.0,146.4,148.7$, 168.0; MS: $m / z=430.28[\mathrm{M}]^{+}$; analysis: for $\mathrm{C}_{21} \mathrm{H}_{17} \mathrm{Cl}_{2} \mathrm{~N}_{3} \mathrm{O}_{3}$ calcd. C 58.62, H 3.98, N 9.77\%; found C 58.84, H 3.99, N 9.80\%.

2.4.13. 2-[2-(2,6-Dichloroanilino)phenyl]-N'-[(2,5-dihydroxyphenyl)methylidene] acetohydrazide (13). Yield: 72\%; m.p.: $130-132{ }^{\circ} \mathrm{C} ;{ }^{1} \mathrm{H}$ NMR $\left(500 \mathrm{MHz}, \mathrm{DMSO}-\mathrm{d}_{6}\right): \delta=3.72(1 \mathrm{H}, \mathrm{s}$, $\left.\mathrm{CH}_{2}\right), 4.13\left(1 \mathrm{H}, \mathrm{s}, \mathrm{CH}_{2}\right), 6.33-7.75(10 \mathrm{H}, \mathrm{m}, \mathrm{Ar}-\mathrm{H}), 8.05(1 \mathrm{H}$, $\mathrm{s},=\mathrm{CH}), 8.41\left(1 \mathrm{H}, \mathrm{s}, \mathrm{NHPh}, \mathrm{D}_{2} \mathrm{O}\right.$ exchg.), $9.0(1 \mathrm{H}, \mathrm{s}, \mathrm{OH}$, $\mathrm{D}_{2} \mathrm{O}$ exchg.), 10.10 (1H, s, OH, $\mathrm{D}_{2} \mathrm{O}$ exchg.), $11.94(1 \mathrm{H}, \mathrm{s}$, CONH, $\mathrm{D}_{2} \mathrm{O}$ exchg.); ${ }^{13} \mathrm{C}$ NMR (125.76 MHz, DMSO-d 6 ): $\delta=108.9,113.7,117.5,119.5,121.3,123.3,125.4,128.2$, $129.8,132.3,134.9,137.5,143.2,143.4,147.1,150.3,150.5$, 167.9, 173.7; MS: $m / z=430.28[\mathrm{M}]^{+}$; analysis: for $\mathrm{C}_{21} \mathrm{H}_{17} \mathrm{Cl}_{2} \mathrm{~N}_{3} \mathrm{O}_{3}$ calcd. C 58.62, $\mathrm{H}$ 3.98, N 9.77\%; found $\mathrm{C}$ 58.80, H 3.99, N 9.74\%. 
2.4.14. 2-[2-(2,6-Dichloroanilino)phenyl]-N'-[(2,3,4-trihydroxyphenyl)methylidene]acetohydrazide (14). Yield: 70\%; m.p.: $153-155^{\circ} \mathrm{C} ;{ }^{1} \mathrm{H}$ NMR (500 MHz, DMSO- $\left.\mathrm{d}_{6}\right): \delta=3.71$ $\left(1 \mathrm{H}, \mathrm{s}, \mathrm{CH}_{2}\right), 4.06\left(1 \mathrm{H}, \mathrm{s}, \mathrm{CH}_{2}\right), 6.32-7.54(9 \mathrm{H}, \mathrm{m}, \mathrm{Ar}-\mathrm{H})$, $8.06(1 \mathrm{H}, \mathrm{s},=\mathrm{CH}), 8.28\left(1 \mathrm{H}, \mathrm{s}, \mathrm{NHPh}, \mathrm{D}_{2} \mathrm{O}\right.$ exchg. $), 8.53(1 \mathrm{H}$, s, $\mathrm{OH}, \mathrm{D}_{2} \mathrm{O}$ exchg. $), 9.52\left(1 \mathrm{H}, \mathrm{s}, \mathrm{OH}, \mathrm{D}_{2} \mathrm{O}\right.$ exchg. $), 11.25(1 \mathrm{H}$, s, OH, $\mathrm{D}_{2} \mathrm{O}$ exchg.), $11.92\left(1 \mathrm{H}, \mathrm{s}, \mathrm{CONH}, \mathrm{D}_{2} \mathrm{O}\right.$ exchg. $) ;{ }^{13} \mathrm{C}$ NMR $\left(125.76 \mathrm{MHz}, \mathrm{DMSO}-\mathrm{d}_{6}\right): \delta=108.1,111.1,116.5$, $121.3,121.5,125.0,125.8,128.0,129.7,130.0,131.0,133.1$, $137.5,143.4,147.8,149.2,150.0,167.6,172.4$; MS: $m /$ $z=446.28[\mathrm{M}]^{+}$; analysis: for $\mathrm{C}_{21} \mathrm{H}_{17} \mathrm{Cl}_{2} \mathrm{~N}_{3} \mathrm{O}_{4}$ calcd. C 56.52, $\mathrm{H} 3.84, \mathrm{~N} 9.42 \%$; found $\mathrm{C} 56.74, \mathrm{H} \mathrm{3.83,} \mathrm{N} \mathrm{9.45 \% .}$

2.5. Pharmacological Activities. Healthy male Westar rats (200-220 g) and albino mice (20-25g) were used for the present study. The animals (132 Westar rats and 126 albino mice) were kept in groups of six animals in each standard plastic animal cages. Animal standard diet and water were fed to the animals before the experiment. The study protocol was approved by the Research Ethics Committee, College of Pharmacy, King Saud University, Saudi Arabia (Research Ethics Number: KSU-SE-20-53). The research adheres to the guide for the care and use of laboratory animals; $8^{\text {th }}$ edition, National Academies Press, Washington, DC [https:// oacu.oir.nih.gov/regulations-standard] [26].

2.5.1. Carrageenan-Induced Paw Edema in Rats. An injection wad made of $0.05 \mathrm{~mL}$ of $1 \%$ carrageenan sodium salt $(\mathrm{BDH})$ into the right hind foot of each rat under the plantar aponeurosis. The test group of rats was treated with equimolar doses orally with test drugs 1 hour before carrageenan injection. At the same time, the control group was given $5 \mathrm{~mL} / \mathrm{kg}$ of normal saline and the reference group was given $10 \mathrm{mg} / \mathrm{kg}$ orally of an aqueous solution of diclofenac in 5\% methyl cellulose. Percent inhibition was calculated taking the values in the control group as $0 \%$ inhibition. The measurements of foot volume were done by the displacement technique using a plethysmometer (Apelex, France) immediately after and $+1,+2$, and +3 hours after the injection of carrageenan. The inhibitory activity was calculated to the following formula $100(1-a-x / b-y)$, where " $b$ " is the mean paw volume of control rats after carrageenan injection and " $y$ " before the injection whereas " $x$ " is the mean paw volume of treated rats before injection and " $a$ " is the mean paw volume after carrageenan injection. Student's $t$-test was used for the statistical calculations [27].

2.5.2. Analgesic Activity by Hot Plate Method. The hot plate method is used for evaluating analgesic activity. The hot plate was maintained at $55.0 \pm 5.5^{\circ} \mathrm{C}$. Albino mice were used in the hot plate method. The reaction time was taken as the interval extending from the instant the animal reached the hot plate until the moment the animal licked its forefeet or jumped off. The mouse was monitored carefully for the time in seconds in which it displayed nociceptive responses, considered as the control reaction time. To avoid damage to the paws, a cutoff time of $60 \mathrm{~s}$ was used. The activity was evaluated after p.o. administration of diclofenac or test compounds at the equimolar dose each. The reaction time was then retested at $0 \mathrm{~h}$ and 30,60, and $120 \mathrm{~min}$ after injection (each animal acted as its own control). The percentage changes in the reaction were then calculated. Student's $t$-test was used for the statistical calculations [28].

2.5.3. Analgesic Activity by Writhing Test. Mice of either sex with a weight between 20 and $25 \mathrm{~g}$ were used. Solution of $0.1 \mathrm{~mL}$ of $0.6 \%$ solution of acetic acid was injected intraperitoneally. Groups of 6 animals were used for control and treated mice. Test animals were administered the test compounds or the standard drug with equimolar doses at various pretreatment times prior to acetic acid administration. The mice were placed individually into glass beakers. The mice were then observed for a period of twenty minutes and the number of writhes was recorded. The formula for computing percent inhibition is as follows: average writhes in the control group minus writhes in the drug group divided by writhes in the control group times $100 \%[29,30]$. Student's $t$-test was used for the statistical calculations.

2.5.4. Ulcerogenic Activity. Wistar rats were used for the ulcerogenic activity. The ulcerogenic activity was checked after peroral administration of an equimolar dose of diclofenac or test compounds. The control group was given a suspension of $1 \%$ methyl cellulose perorally. The animals were euthanized by using pentobarbitone $(50 \mathrm{mg} / \mathrm{kg})$ intraperitoneal before cervical dislocation. The stomach was opened along the greater curvature and washed with distilled water. A magnifying glass was used to examine the mucosal damage. For each stomach, the mucosal damage was assessed according to the reported scoring system [31, 32]. Data expressed as ulcer index. Student's $t$-test was used for the statistical calculations.

2.5.5. Determination of $L D_{50}$. The Karber method was used to determine the median lethal dose $\left(\mathrm{LD}_{50}\right)$ of compound 8 . An observation was made for $24 \mathrm{~h}$ after the dosing of animals. Dead rats were counted at the end of the study period. The Karber formula was used for the calculation of $\mathrm{LD}_{50}$. For determination of $\mathrm{LD}_{50}$, an observation was made for 24 hours and symptoms of toxicity and rate of mortality were noted. Expired animals were counted at the end of the study period for the calculation of $\mathrm{LD}_{50}$. $\mathrm{LD}_{50}=\mathrm{LD}_{100}-\sum \times((a \times b) / n)$, where $n$ is the total number of animals in a group, a is the difference between two successive doses of administered extract/substance, $b$ is the average number of dead animals in two successive doses, and $\mathrm{LD}_{100}$ is the lethal dose causing $100 \%$ death of all test animals [33].

2.5.6. Docking Studies of Compounds. Molecular docking simulations were performed to reinforce the wet-lab analysis and get insight into the molecular mechanism of inhibition of COX-1 and COX-2 by the drugs. Three-dimensional 
structure of COX-1 was downloaded from PDB (6Y3C). It is a recently resolved human COX-1 structure. Usually, in previous studies, COX-1 structures from other organisms were employed for molecular docking, which might bring some discrepancies in the results. The COX-2 three-dimensional structure was also downloaded from PDB (5F1A). The downloaded structures were visualized using PyMol and refined for the docking process by removing all of the bounded ligands and water molecules. Likewise, three-dimensional structures of all synthetic compounds were developed using Chem 3D Pro 12.0 version. The structure of a standard compound (Diclofenac) was downloaded from the PubChem database. Finally, the molecular docking simulation was performed using the CB-Dock online server. This server used Autodock vina at the backend to perform docking analysis. The docking poses of drugs with the protein structures were ranked as per decreasing energies values. The best docking pose usually has the lowest energy. The two-dimensional and three-dimensional bindings of the drugs with the proteins were visualized using LigPlot and PyMol.

\section{Results and Discussion}

To synthesize various substituted diclofenac hydrazones, the hydrazide of diclofenac (III) was used as a starting material [28]. The diclofenac hydrazide was obtained from diclofenac ester (methyl [2-(2,6-dichloroanilino)phenyl]acetate (II), which was reacted with hydrazine hydrate $99 \%$ in absolute ethanol. Hydrazones of diclofenac (1-14) were synthesized by reacting diclofenac hydrazide (III) with different substituted benzaldehydes in ethanol with few drops of glacial acetic acid, used as a catalyst in this reaction. The preparation of hydrazones of diclofenac was performed as per Scheme 1. Moreover, the structures were characterized by spectroscopic methods, elemental analysis, and mass spectrometry. The structure of the diclofenac hydrazide (III) has presented an identical NMR splitting pattern as that of diclofenac. The structures of the diclofenac acid hydrazide derivatives were confirmed on the basis of ${ }^{1} \mathrm{H}$ NMR analysis, which was established by the disappearance of $-\mathrm{NH}_{2}$ protons at $\delta 1.97 \mathrm{ppm}$. Mass spectra confirmed the molecular masses of compounds by their molecular ion peaks.

3.1. Anti-Inflammatory Activity. The anti-inflammatory activity of the synthesized compounds (1-14) was evaluated by the carrageenan-induced paw edema method. The antiinflammatory activity ranges between $7.69 \%$ and $60.16 \%$ inhibition after $2 \mathrm{~h}$. The inhibition was $11.20 \%$ to $65.48 \%$, after $3 \mathrm{~h}$, compared to the reference drug diclofenac that showed $64.56 \%$ inhibition after $2 \mathrm{~h}$ and $69.02 \%$ inhibition after $3 \mathrm{~h}$. The compounds $(2,3,7,8,11$, and 13) were found to be the most promising compounds (Table 1). Because of their hydrazide substitution, significant anti-inflammatory activity was observed. However, the substitution of the hydrazide with 3,5-dimethoxy-4-hydroxyphenyl as in compound 8 has shown $60.16 \%$ inhibition after $2 \mathrm{~h}$ and $65.48 \%$ inhibition after $3 \mathrm{~h}$, whereas the substitution with 2,4-dimethoxyphenyl as in compound 3 was observed to have $53.84 \%$ and $61.65 \%$ inhibition after $2 \mathrm{~h}$ and $3 \mathrm{~h}$, respectively. These observations provided the base for further testing and development of these compounds. The diclofenac hydrazone derivatives having 2,3-dimethoxyphenyl, 2,4-dimethoxyphenyl, 3-ethoxy-2-hydroxyphenyl, 3,5dimethoxy-4-hydroxyphenyl, 3-methoxy-4-ethoxyphenyl, and 2,5-dihydroxyphenyl substitutions showed the significant anti-inflammatory activity. The lowest anti-inflammatory activity was shown by the compound containing 2,4,5-trimethoxyphenyl substitution.

3.2. Analgesic Activity by Hot Plate Method. Analgesic activity was determined by the hot plate method. Based on the results of anti-inflammatory activity, compounds that showed significant anti-inflammatory activity were further tested for their analgesic activity (Table 2). Compound $8(R=3,5$ dimethoxy-4-hydroxyphenyl) expressed highly significant analgesic activity of $204 \%$ change, compared with the reference drug diclofenac with $183.33 \%$ change. The analgesic activity of compound 3 ( $R=2,4$-dimethoxyphenyl) was found to be $172 \%$ change. Substitution with 2,5 -dihydroxyphenyl has shown analgesic activity of $135.48 \%$ change in compound 13. Compounds 3,8 , and 13 have a significant analgesic activity as compared to the reference drug diclofenac.

\subsection{Analgesic Activity of Compounds by Acetic Acid-Induced} Writhing. To confirm the analgesic activity of compounds that showed good anti-inflammatory activity, the compounds were further tested for analgesic activity by acetic acid-induced writhing test in mice (Table 3). Acetic acid was used for testing analgesic activity. Compound $13(R=2,4$-dimethoxyphenyl), compound $3(R=2,4$-dimethoxyphenyl), and compound 8 ( $R=3,5$-dimethoxy-4-hydroxyphenyl) expressed highly significant analgesic activity of $76.60,76.09$, and $76.09 \%$ inhibition, respectively, as compared to the reference drug diclofenac with $76.58 \%$ inhibition. Compound $11 \quad(R=3$ Methoxy-4-ethoxyphenyl) also expressed significant activity of 69.75 .

3.4. Ulcerogenic Activity. The compounds which showed highly significant anti-inflammatory and analgesic activity were screened for ulcerogenic activity (Table 4). Gastric mucosal damage was examined after oral administration of the test compounds. Ulcerogenic reduction activity between 0.00 and $0.50 \pm 0.22$ was observed in test compounds as compared to the diclofenac with an ulcer index of $0.66 \pm 0.21$. Compounds 3 and 8 showed maximum ulcerogenic reduction activities.

3.5. Toxicity of Compound 8. To determine the median lethal dose $\left(\mathrm{LD}_{50}\right)$ of compound 8 , the Karber method was used. The toxicity symptoms and mortality at $24 \mathrm{~h}$ of observation were made. Compound 8 was found to have the median lethal dose $\left(\mathrm{LD}_{50}\right)$ of $168 \mathrm{mg} / \mathrm{kg}$ (Table 5). 


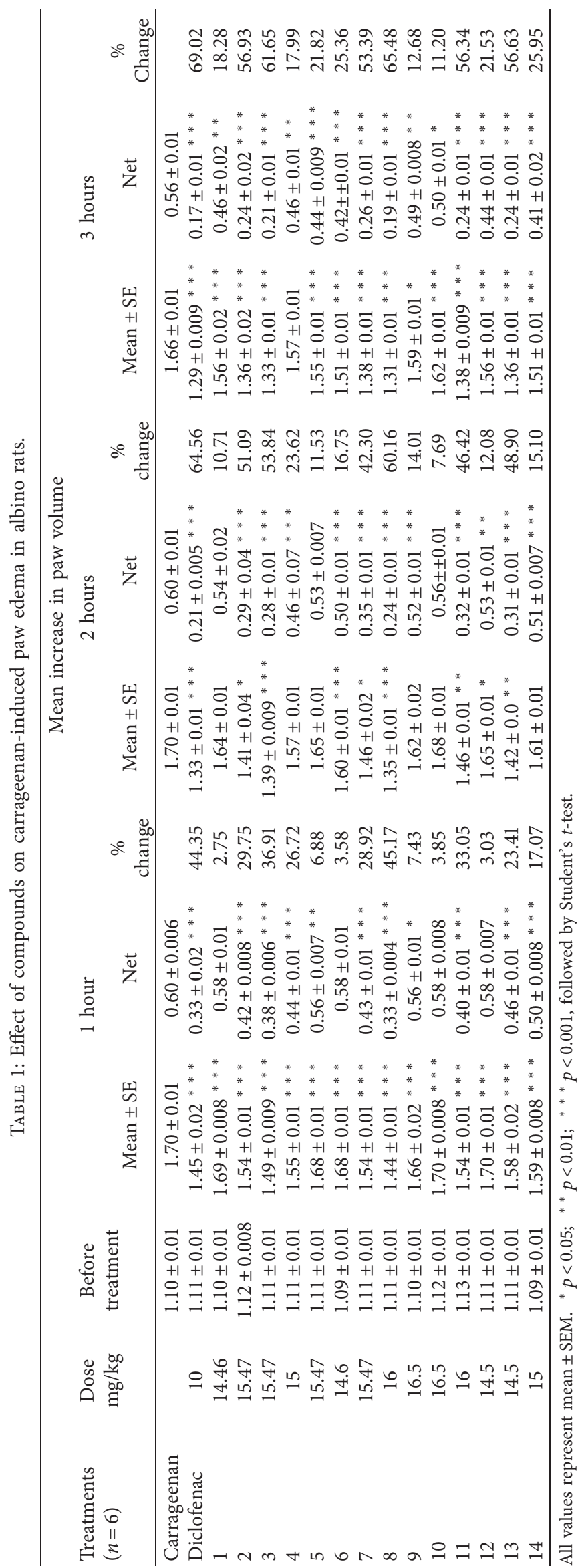


TABLe 2: Analgesic effect of compounds on hot plate reaction time in mice.

\begin{tabular}{|c|c|c|c|c|c|c|c|c|}
\hline \multirow{3}{*}{ Treatment $(n=6)$} & \multirow{3}{*}{ Dose $(\mathrm{mg} / \mathrm{kg})$} & \multirow{3}{*}{ Predrug } & \multicolumn{6}{|c|}{ Reaction time (seconds) postdrug } \\
\hline & & & \multicolumn{2}{|l|}{$30 \mathrm{~min}$} & \multicolumn{2}{|l|}{$60 \mathrm{~min}$} & \multicolumn{2}{|c|}{$120 \mathrm{~min}$} \\
\hline & & & Mean \pm SE & $\%$ change & Mean \pm SE & $\%$ change & Mean \pm SE & $\%$ change \\
\hline Diclofenac & 10 & $5.00 \pm 0.36$ & $7.33 \pm 0.0 .33 * * *$ & 46.66 & $11.50 \pm 0.60 * * *$ & 130 & $14.16 \pm 0.30^{* * *}$ & 183.33 \\
\hline 2 & 15.47 & $4.33 \pm 0.33$ & $5.00 \pm 0.36$ & 15.38 & $5.50 \pm 0.42 *$ & 26.92 & $6.50 \pm 0.42 * *$ & 50 \\
\hline 3 & 15.47 & $4.16 \pm 0.30$ & $7.66 \pm 0.33^{* * *}$ & 84 & $10.66 \pm 0.71^{* * *}$ & 156 & $11.33 \pm 0.66^{* * *}$ & 172 \\
\hline 7 & 15.47 & $4.16 \pm 0.30$ & $6.50 \pm 0.42 * * *$ & 56 & $5.33 \pm 0.33^{*}$ & 28 & $5.83 \pm 0.30 * *$ & 40 \\
\hline 8 & 16 & $4.16 \pm 0.30$ & $7.33 \pm 0.33 * * *$ & 76 & $10.33 \pm 0.42 * * *$ & 148 & $12.66 \pm 0.33^{* * *}$ & 204 \\
\hline 11 & 16 & $4.83 \pm 0.30$ & $5.66 \pm 0.42$ & 17.24 & $5.33 \pm 0.33$ & 10.34 & $6.33 \pm 0.33 * *$ & 31.03 \\
\hline 13 & 14.5 & $5.16 \pm 0.30$ & $8.66 \pm 0.46^{* * *}$ & 67.74 & $10.83 \pm 0.74 * * *$ & 109.67 & $12.16 \pm 0.60 * * *$ & 135.48 \\
\hline
\end{tabular}

All values represent mean \pm SEM. ${ }^{*} p<0.05 ;{ }^{* *} p<0.01 ;{ }^{* * *} p<0.001$, followed by Student's $t$-test.

TABLE 3: Analgesic activity of compounds by acetic acid-induced.

\begin{tabular}{lccr}
\hline Treatments $(n=6)$ & Dose $(\mathrm{mg} / \mathrm{kg})$ & Number of writhing in $20 \mathrm{~min}$. & \% inhibition \\
\hline Control (acetic acid) & & $34.16 \pm 1.41$ & 76.58 \\
Diclofenac & 10 & $8.00 \pm 0.57^{* * *}$ & 27.31 \\
2 & 15.47 & $24.83 \pm 0.79 * * *$ & 76.09 \\
3 & 15.47 & $8.16 \pm 0.83^{* * *}$ & 56.85 \\
7 & 15.47 & $14.83 \pm 1.01^{* * *}$ & 76.09 \\
8 & 16 & $8.16 \pm 0.47^{* * *}$ & 69.75 \\
11 & 16 & $10.33 \pm 0.80^{* * *}$ & 76.60 \\
13 & 14.5 & $8.03 \pm 0.42^{* * *}$ & \\
\hline
\end{tabular}

All values represent mean \pm SEM. ${ }^{* * *} p<0.001$, followed by Student's $t$-test.

TABLE 4: Ulcer study of active compounds.

\begin{tabular}{lcc}
\hline Name of compounds & Dose $\mathrm{mg} / \mathrm{kg}$ & Ulcer index \\
\hline Diclofenac & 10 & $0.66 \pm 0.21$ \\
3 & 15.47 & $00.00 \pm 00.00$ \\
8 & 16 & $00.00 \pm 00.00$ \\
11 & 16 & $0.16 \pm 0.02$ \\
13 & 14.5 & $0.50 \pm 0.22$ \\
Control & - & $00.00 \pm 00.00$ \\
\hline
\end{tabular}

TABLE 5: LD50 of compound 8 by The Karber method.

\begin{tabular}{lccccc}
\hline Group & Dose mg/kg & DF (a) & Dead & MM (b) & Pro. ( $\left.\mathrm{a}^{*} \mathrm{~b}\right)$ \\
\hline 1 & 16 & & 0 & & \\
2 & 32 & 16 & 0 & & \\
3 & 64 & 32 & 1 & 0.5 & 16 \\
4 & 128 & 64 & 4 & 2.5 & 160 \\
5 & 256 & 128 & 9 & 6.5 & 832 \\
6 & 512 & 256 & 10 & 9.5 & 2432 \\
& & & & & 3440 \\
& & & & & $168 \mathrm{mg} / \mathrm{kg}$ \\
\hline
\end{tabular}

3.6. Molecular Docking. The molecular docking simulations were performed using CB-Dock online server. This server employed Auto dock vina for protein-ligand docking. Usually, the binding affinity of the docked ligand with the protein is estimated with vina score, which is also known as docking energies $(\mathrm{kJ} / \mathrm{mol})$. The best-docked compound typically demonstrates low vina score or docking energies. The accuracy of CB-Dock server is estimated to be $\sim 70 \%$, which is better than its contemporary tools. Compound 8 (3,5-dimethoxy-4- hydroxyphenyl) showed better binding affinities with COX-1/ COX-2 $(-9.4 \mathrm{~kJ} / \mathrm{mol})$ protein structures as compared to the standard drug, diclofenac (Table 6). Interestingly, diclofenac demonstrated approximately $20 \%$ better affinity with COX-2 $(-8.1 \mathrm{~kJ} / \mathrm{mol})$ as compared to COX-1 $(-6.6 \mathrm{~kJ} / \mathrm{mol})$. This data is consistent with previous experimental findings as well [34]. The visualization of the docked complexes revealed that diclofenac bounded with COX-1 and COX-2 in a small cavity at the same position (Figures 1 and 2). It seems to be very rational as both proteins share $70 \%$ sequence identity and very similar type of three-dimensional structures [35]. However, compound 8 did not bind in the same cavity where diclofenac was docked in both proteins. One of the potential reasons for this phenomenon may be the large size of compound 8 as compared to diclofenac. Compound 8 docked at the same position in both proteins as it can be visualized in Figures 3 and 4 . The drug showed similar binding affinities with COX-1 and COX-2 $(-9.4 \mathrm{~kJ} / \mathrm{mol})$. In COX-1, the prominent interactions are hydrophobic while, in COX-2 hydrogen, binding seems to be more critical as compared to hydrophobic interactions (Figure 5). 


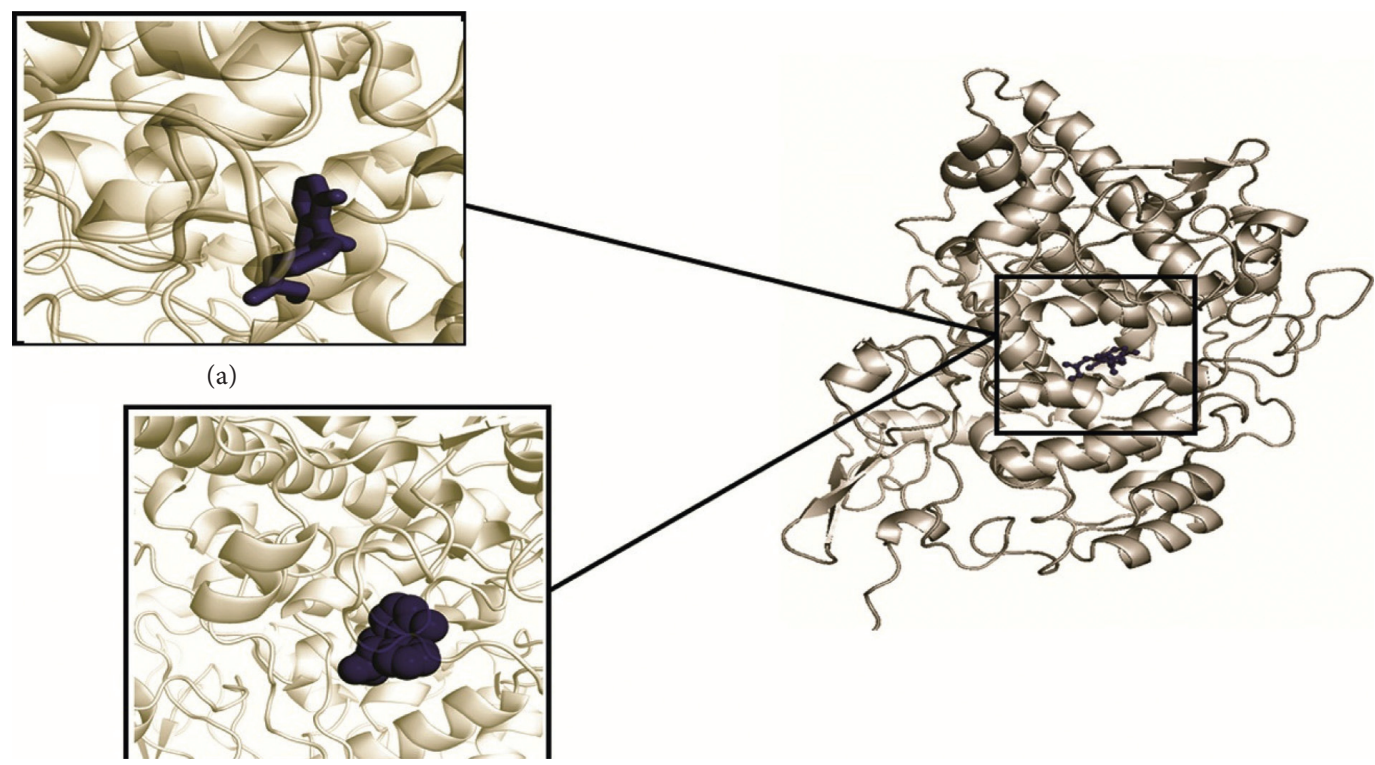

(b)

Figure 1: Binding of standard drug, diclofenac with COX-1 protein. (a) Representation of diclofenac binding with COX-1 in ball and stick form. (b) Representation of diclofenac binding with COX-1 in ball and space fill form.

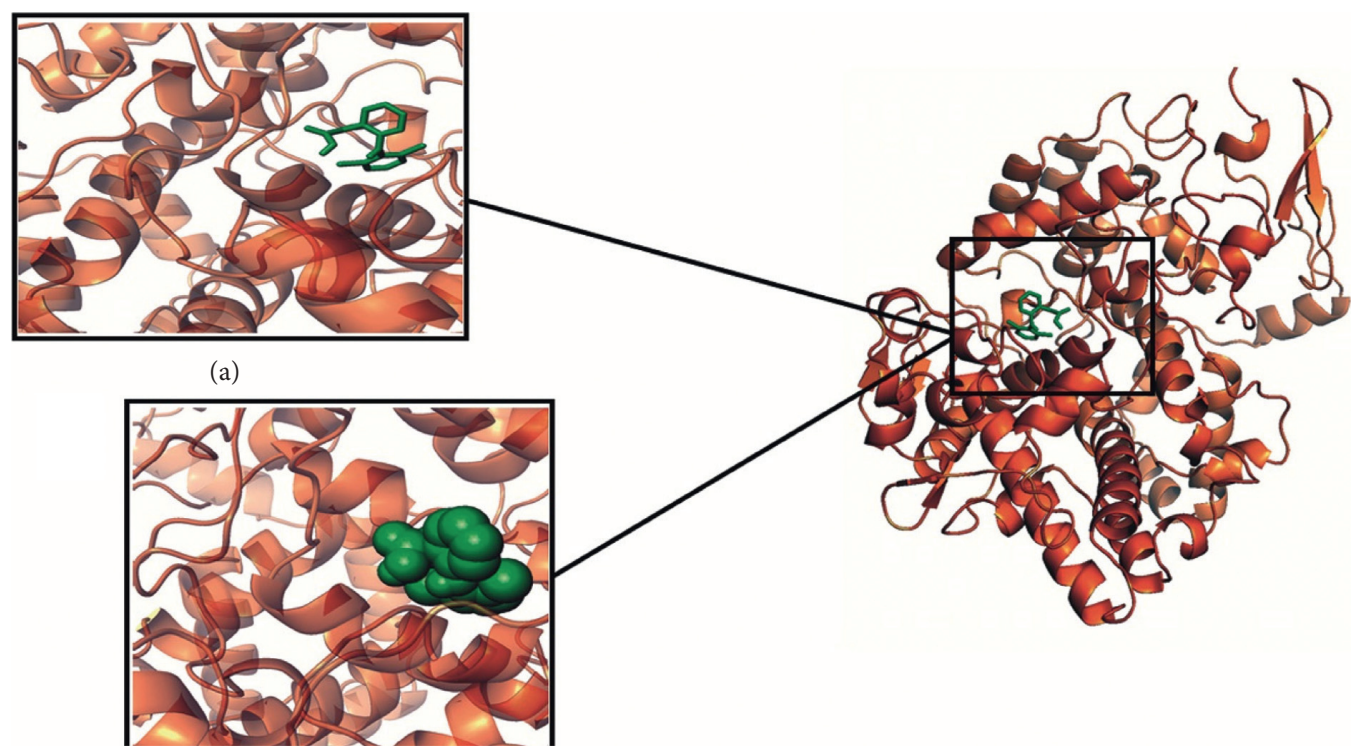

(b)

FIgURE 2: Binding of standard drug, diclofenac with COX-2 protein. (a) Representation of diclofenac binding with COX-2 in ball and stick form. (b) Representation of diclofenac binding with COX-2 in ball and space fill form.

TABLE 6: Docking energies of the compounds with COX-1 and COX-2 proteins.

\begin{tabular}{lccccc}
\hline Compd. & $\begin{array}{c}\text { Energies } \\
\text { Cox-1 }(\mathrm{kJ} / \mathrm{mol})\end{array}$ & $\begin{array}{c}\text { Energies } \\
\text { Cox-2 }(\mathrm{kJ} / \mathrm{mol})\end{array}$ & Compd. & $\begin{array}{c}\text { Energies } \\
\text { Cox-1 }(\mathrm{kJ} / \mathrm{mol})\end{array}$ & $\begin{array}{c}\text { Energies } \\
\text { Cox-2 }(\mathrm{kJ} / \mathrm{mol})\end{array}$ \\
\hline 1 & -8.8 & -10 & 8 & -9.4 & -8.3 \\
2 & -8.4 & -10 & 9 & -8.3 & -9.4 \\
3 & -8.7 & -9.9 & 10 & -8.4 & -9.6 \\
4 & -9.2 & -9.8 & 11 & -9.1 & -9.5 \\
5 & -8.5 & -9.7 & 12 & -9.8 & -9.9 \\
6 & -8.5 & -10.4 & 13 & -8.8 & -10 \\
7 & -8.2 & -9.6 & Diclofenac & -6.6 & -8.1 \\
\hline
\end{tabular}


<smiles>COC(=O)Cc1ccccc1NC(=O)CCCCO</smiles><smiles>[R]C=NNC(=O)Cc1ccccc1Nc1c(Cl)cccc1Cl</smiles>

\begin{tabular}{clcl}
\hline Compd. & \multicolumn{1}{c}{$\mathrm{R}$} & Compd. & \multicolumn{1}{c}{$\mathrm{R}$} \\
\hline 1 & 3-Methoxyphenyl & 8 & 3,5-Dimethoxy-4-hydroxyphenyl \\
2 & 2,3-Dimethoxyphenyl & 9 & 2,4,6-Trimethoxyphenyl \\
3 & 2,4-Dimethoxyphenyl & 10 & 2,4,5-Trimethoxyphenyl \\
4 & 2-Hydroxy-3-methoxyphenyl & 11 & 3-Methoxy-4-ethoxyphenyl \\
5 & 3-Ethoxy-4-hydroxyphenyl & 12 & 2,3-Dihydroxyphenyl \\
6 & 4-Chlorophenyl & 13 & 2,5-Dihydroxyphenyl \\
7 & 3-Ethoxy-2-hydroxyphenyl & 14 & 2,3,4-Trihydroxyphenyl
\end{tabular}

Scheme 1: Synthetic route for the synthesis of compounds (1-14).

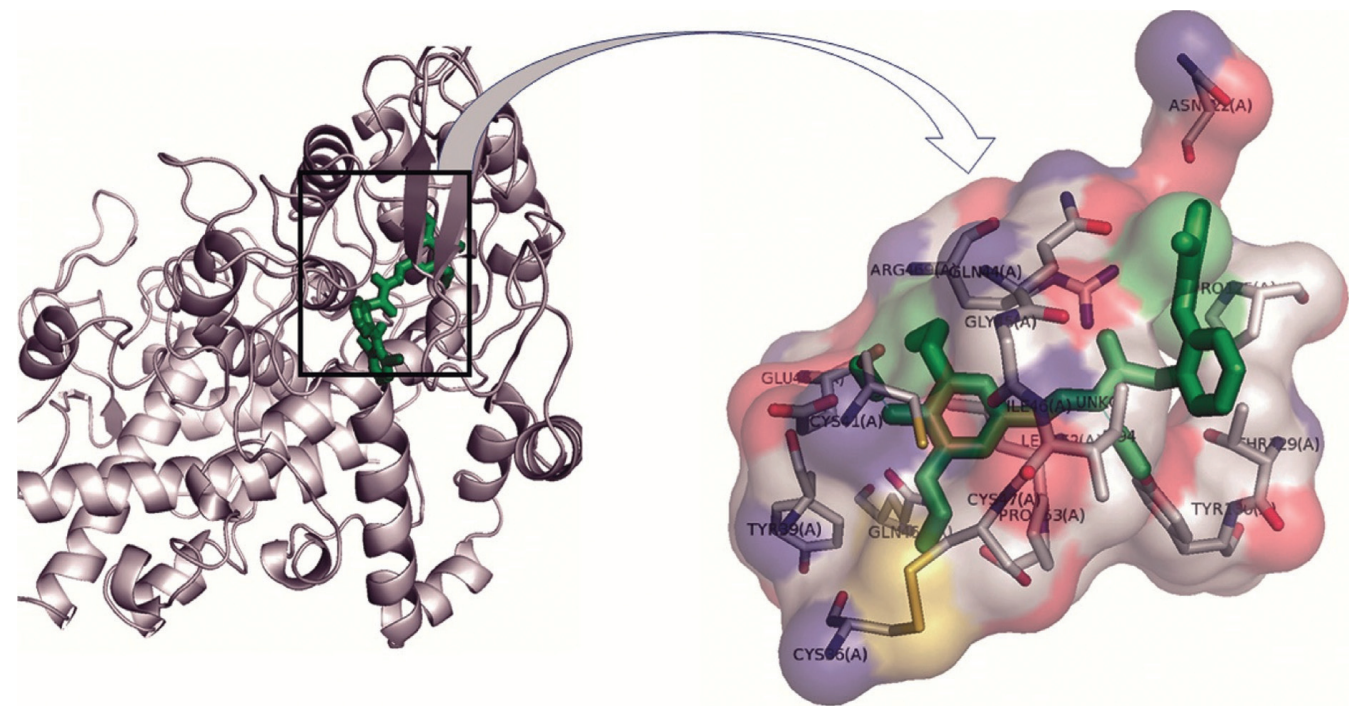

FIgURE 3: Binding of compound 8 with COX-1 protein. In zoom-in subset, the amino acid residues which are involved in the binding with the drug can be seen. 


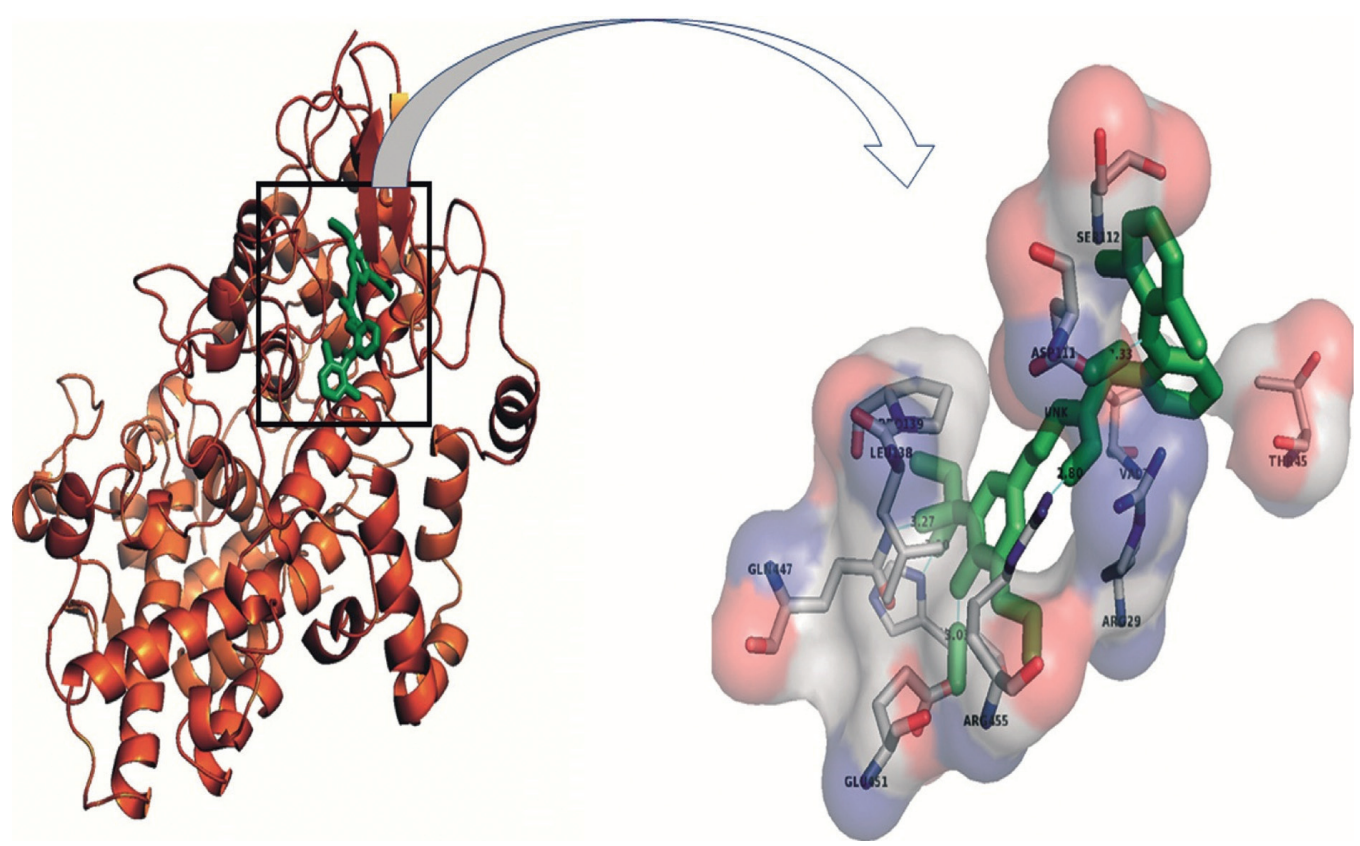

FIGURE 4: Binding of compound 8 with COX-2 protein. In zoom-in subset, the amino acid residues which are involved in the binding with the drug can be seen.

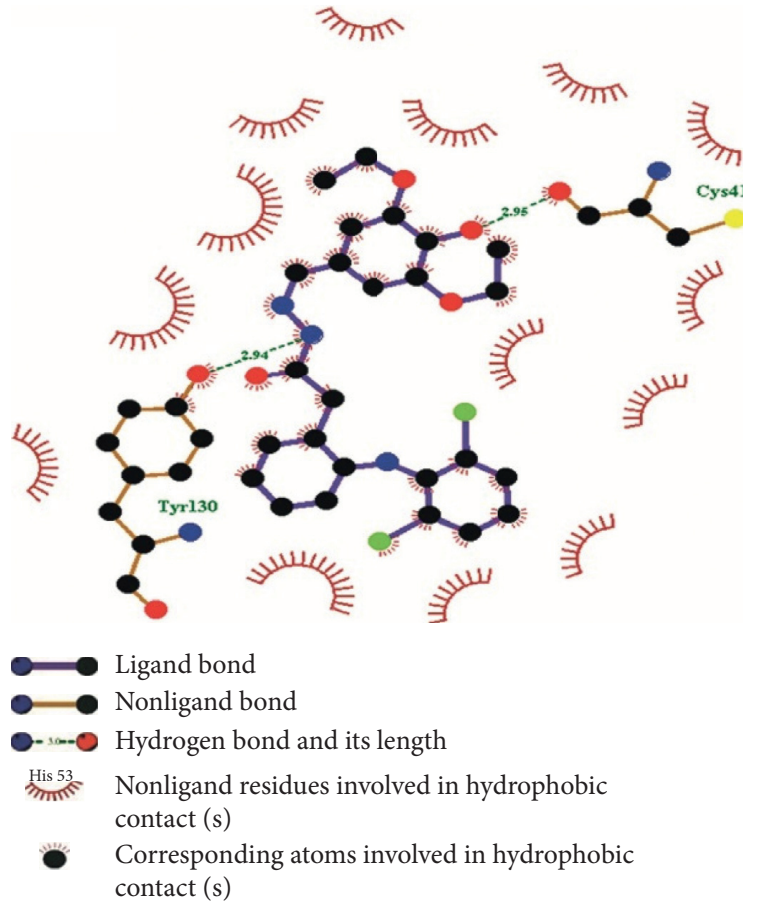

(a)

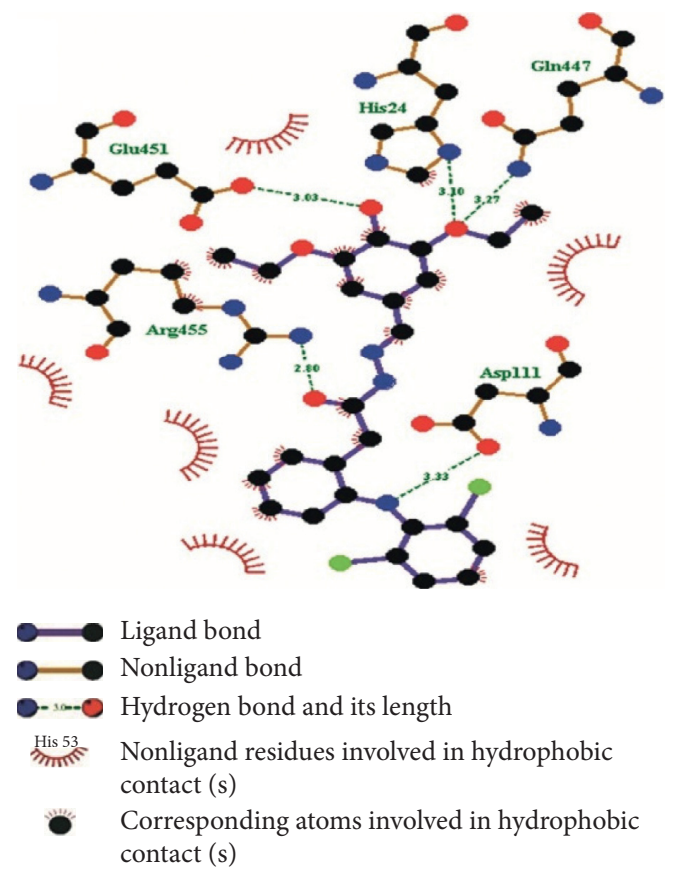

(b)

Figure 5: 2D representation of binding of compound 8 with COX-1 and COX-2. (a) Binding of compound 8 with COX-1 amino acid residues. It can be seen that compound 8 is making hydrogen bonds with Try-130 and Cys- 41 (green dotted line) while the majority of interactions are hydrophobic in nature. (b) Binding of compound 8 with COX-2 amino acid residues. It can be seen that compound 8 is making hydrogen bonds with Asp-111, Glu-451, Gln447, Arg-455 Arg-445 (green dotted line) while majority of interactions are hydrophobic in nature. 


\section{Conclusions}

Novel diclofenac hydrazones (1-14) were prepared in excellent yield. The synthesized compounds were confirmed by the elemental analysis and spectral data. Chemical modification to the diclofenac hydrazide resulted in fourteen new diclofenac hydrazones. The compounds $(2,3,7,8,11$, and 13) were found to be the most promising compounds in anti-inflammatory activity. Compounds 3,8 , and 13 have been found to have significant analgesic activity compared to the reference drug diclofenac in analgesic activity by both hot plate and acetic acid-induced writhing method. Compound 8 containing 3,5-dimethoxy-4-hydroxyphenyl substitution was found to be a highly potent anti-inflammatory and analgesic agent. It was further evaluated for ulcerogenic activity and demonstrated significant ulcerogenic reduction activity. The median lethal dose of compound 8 was found to be $168 \mathrm{mg} / \mathrm{kg}$. Compound 8 with 3,5-dimethoxy-4hydroxyphenyl substitution was found to be the most promising anti-inflammatory and analgesic agent with gastric sparing activity.

\section{Highlights}

Synthesis of novel diclofenac hydrazones.

Spectral characterization of synthesized compounds.

In vivo anti-inflammatory, analgesic, and ulcerogenic activity of compounds.

$\mathrm{LD}_{50}$ determination of most potent compound.

Molecular docking of synthesized compounds against COX-1/COX-2 binding site.

\section{Data Availability}

Samples of the compounds (1-14) in pure form are available from the authors upon request.

\section{Conflicts of Interest}

The authors declare that they have no known competing financial interests or personal relationships that could have appeared to influence the work reported in this paper.

\section{Acknowledgments}

The authors would like to extend their sincere appreciation to the Deanship of Scientific Research at King Saud University for funding this research group (no. RG 1435-006).

\section{References}

[1] C. A. C. Vasilios, A. S. Koutakis, R. Timothy et al., "Review of diclofenac and evaluation of its place in therapy as a nonsteroidal antiinflammatory agent," Drug Intelligence Clinical Pharmacy, vol. 22, pp. 850-859, 1988.

[2] C. Almansa, J. Alfón, A. F. de Arriba et al., "Synthesis and Structure-Activity relationship of a new series of COX-2 selective inhibitors: 1,5-diarylimidazoles," Journal of Medicinal Chemistry, vol. 46, no. 16, pp. 3463-3475, 2003.
[3] A. S. H. Da Silva Guerra, D. J. Do Nascimento Malta, L. P. Morais Laranjeira et al., "Anti-inflammatory and antinociceptive activities of indole-imidazolidine derivatives," International Immunopharmacology, vol. 11, no. 11, pp. 1816-1822, 2011.

[4] Y. S. Yaseen, M. S. Farhan, and S. J. Salih, "Synthesis and evaluation of new diclofenac acid having 2-azetidinone," Der Pharma Chemica, vol. 9, pp. 44-49, 2017.

[5] S. B. Suryawanshi, H. A. Osman, Y. I. Shaikh, and G. M. Nazeruddin, "Synthesis of various esters of diclofenac (NSAIDs) as pro-drugs and their biological evaluation," Chemical Science Transactions, vol. 3, pp. 562-565, 2014.

[6] P. L. Bosquesi, T. R. F. Melo, E. O. Vizioli, J. L. D. Santos, and M. C. Chung, "Anti-inflammatory drug design using a molecular hybridization approach," Pharmaceuticals, vol. 4, no. 11, pp. 1450-1474, 2011.

[7] J. L. dos Santos, V. Moreira, and M. L. Campos, "Pharmacological evaluation and preliminary pharmacokinetics studies of a new diclofenac prodrug without gastric ulceration effect," International Journal of Molecular Science, vol. 13, pp. 15305-15320, 2012.

[8] A. A. Patil and A. P. Sarkate, "Anti-Inflammatory, Analgesic, Ulcerogenic Activities of some new non-acidic diclofenac and 1, 3, 4-oxadiazole derivatives in animal models," Pharmacologyonline, vol. 186, pp. 172-186, 2007.

[9] A. Elhenawy and H. M. Mohmmed, "Synthesis, anti-Inflammatory, analgesic, molecular modeling and ADMET studies of novel diclofenac derivatives containing alanyl moiety," Chemical Materials Research, vol. 6, pp. 69-77, 2014.

[10] S. E. Abbas, H. E. Abou-Youssef, G. M. El-Taliawi, and A. B. Hassan, "Synthesis of certain 1,3,4-oxadiazole derivatives of expected anti-inflammatory activity," Egypt Journal of Pharmaceutical Science, vol. 32, pp. 515-527, 1991.

[11] S. V. Bhandari, K. G. Bothara, M. K. Raut, A. A. Patil, A. P. Sarkate, and V. J. Mokale, "Design, synthesis and evaluation of antiinflammatory, analgesic and ulcerogenicity studies of novel S-substituted phenacyl-1,3,4-oxadiazole-2thiol and Schiff bases of diclofenac acid as nonulcerogenic derivatives," Bioorganic and Medicinal Chemistry, vol. 16, no. 4, p. $1822,2008$.

[12] U. K. Bandarage, L. Chen, X. Fang et al., "Nitrosothiol esters of diclofenac: synthesis and pharmacological characterization as gastrointestinal-sparing prodrugs $\dagger, \ddagger$, Journal of Medicinal Chemistry, vol. 43, no. 21, p. 4005, 2000.

[13] M. B. Palkar, A. S. Singhai, P. M. Ronad et al., "Synthesis, pharmacological screening and in silico studies of new class of Diclofenac analogues as a promising anti-inflammatory agents," Bioorganic \& Medicinal Chemistry, vol. 22, no. 10, p. 2855, 2014.

[14] M. Amir and K. Shikha, "Synthesis and anti-inflammatory, analgesic, ulcerogenic and lipid peroxidation activities of some new 2-[(2,6-dichloroanilino) phenyl]acetic acid derivatives," European Journal of Medicinal Chemistry, vol. 39, no. 6, p. 535, 2004.

[15] D. Sriram, P. Yogeeswari, and R. V. Devakaram, "Synthesis, in vitro and in vivo antimycobacterial activities of diclofenac acid hydrazones and amides," Bioorganic \& Medicinal Chemistry, vol. 14, no. 9, p. 3113, 2006.

[16] A. S. Kalgutkar, B. C. Crews, S. W. Rowlinson et al., "Biochemically based design of cyclooxygenase-2 (COX-2) inhibitors: facile conversion of nonsteroidal antiinflammatory drugs to potent and highly selective COX-2 inhibitors," Proceedings of the National Academy of Sciences, vol. 97, no. 2, pp. 925-930, 2000. 
[17] W. S. Abdel-Aal, H. Y. Hassan, T. Aboul-Fadl, and A. F. Youssef, "Pharmacophoric model building for antitubercular activity of the individual Schiff bases of small combinatorial library," European Journal of Medicinal Chemistry, vol. 45, no. 3, pp. 1098-1106, 2010.

[18] R. Chelucci, L. Dutra, M. Lopes Pires et al., "Antiplatelet and antithrombotic activities of non-steroidal anti-inflammatory drugs containing an N-acyl hydrazone subunit," Molecules, vol. 19, no. 2, pp. 2089-2099, 2014.

[19] T. de Melo, R. Chelucci, M. Pires et al., "Pharmacological evaluation and preparation of nonsteroidal anti-inflammatory drugs containing an $\mathrm{N}$-acyl hydrazone subunit," International Journal of Molecular Sciences, vol. 15, no. 4, pp. 5821-5837, 2014.

[20] M. Bhat, M. Al-Omar, M. Raish et al., "Indole derivatives as cyclooxygenase inhibitors: synthesis, biological evaluation and docking studies," Molecules, vol. 23, no. 6, p. 1250, 2018.

[21] M. A. Bhat, M. A. Al-Omar, M. A. Ansari et al., "Design and synthesis of $\mathrm{N}$-arylphthalimides as inhibitors of glucocorticoid-induced TNF receptor-related protein, proinflammatory mediators, and cytokines in carrageenan-induced lung inflammation," Journal of Medicinal Chemistry, vol. 58, no. 22, p. $8850,2015$.

[22] B. Furniss, A. H. Hannaford, P. W. G. Smith, and A. R. Tatchell, Vogel's Text Book of Practical Organic Chemistryp. 1077, 5th edition, AddisonWesley Longman, Inc, Boston, MA, USA, 1998.

[23] A. Kocabalkanlı, G. Cihan-Üstündağ, L. Naesens, E. Matarac1Kara, M. Nassozi, and G. Çapan, "Diclofenac-based hydrazones and spirothiazolidinones: synthesis, characterization, and antimicrobial properties," Archiv der Pharmazie, vol. 350, no. 5, Article ID e700010, 2017.

[24] D. H. Boschelli, D. T. Connor, M. L. Hoefle, Eur. Pat. Appl. EP401857 A2 19901212, 1990.

[25] A. Focşa, A. I. Iacob, I. M. Vasincu et al., "Optimization of the synthesis of diclofenac derivatives with hydrazone structure and in vitro evaluation of the anti-inflammatory potential," Revista De Chimie, vol. 71, pp. 305-314, 2020.

[26] G. C. Braden, S. Rasmussen, S. Monette, and R. J. Tolwani, "Effects of breeding configuration on maternal and weaning behavior in laboratory mice," Journal of American Association of Laboratory Animal Science, vol. 56, pp. 369-376, 2017.

[27] C. A. Winter, E. A. Risley, and G. W. Nuss, "Carrageenininduced edema in hind paw of the rat as an assay for antiinflammatory drugs," Experimental Biology and Medicine, vol. 111, no. 3, pp. 544-547, 1962.

[28] N. B. Eddy and D. Leimbach, "Synthetic analgesics. II. Dithienylbutenyl- and dithienylbutylamines," The Journal of Pharmacology and Experimental Therapeutics, vol. 107, no. 3, pp. 385-393, 1953.

[29] R. I. Taber, D. D. Greenhouse, J. K. Rendell, and S. Irwin, "Agonist and anatagonsit interaction of opioids on acetic acid-induced abdominal stretching in mice," Journal of Pharmacology and Experimental Therapeutics, vol. 169, pp. 29-38, 1969.

[30] R. Koster, M. Anderson, and D. E. J. Beer, "Acetic acid for analgesic screening," Proceedings of Society for Experimental Biology and Medicine, vol. 18, pp. 412-415, 1959.

[31] M. A. Bhat, M. A. Al-Omar, M. Raish, M. A. Ansari, and H. A. Abuelizz, "Cyclooxygenase I nhibitors," US. Patent. 9808443 B1, 2017.

[32] M. A. Bhat, M. A. Al-Omar, and A. M. Naglah, "Synthesis and in vivo anti-ulcer evaluation of some novel piperidine linked dihydropyrimidinone derivatives," Journal of Enzyme Inhibition \& Medicinal Chemistry, vol. 33, pp. 978-988, 2018.

[33] G. Kärber, "Beitrag zur kollektiven behandlung pharmakologischer reihenversuche," Naunyn-Schmiedebergs Archiv für Experimentelle Pathologie und Pharmakologie, vol. 162, no. 4, pp. 480-483, 1931.

[34] B. Cryer and M. Feldman, "Cyclooxygenase-1 and cyclooxygenase-2 selectivity of widely used nonsteroidal anti-inflammatory drugs," The American Journal of Medicine, vol. 104, no. 5, pp. 413-421, 1998.

[35] C. A. Rouzer and L. J. Marnett, "Cyclooxygenases: structural and functional insights," Journal of Lipid Research, vol. 50, no. Supplement, pp. S29-S34, 2009. 